Marquette University

e-Publications@Marquette

English Faculty Research and Publications

English, Department of

$1-1-2014$

Science Fiction in the United States

Gerry Canavan

Marquette University, gerard.canavan@marquette.edu

Published version. "Science Fiction in the United States," in The American Novel: 1870-1940. Eds. Priscilla Wald and Michael A. Elliott. Oxford: Oxford University Press, 2014: 370-385. Publisher Link. (C) 2014 Oxford University Press. Used with permission. 


\title{
SCIENCE FICTION IN THE UNITED STATES
}

\author{
BY GERRY CANAVAN
}

c6To be modern," Marshall Berman writes in his seminal work on the intertwined origins of modernity, modernism, and Marxism, All That Is Solid Melts into Air, "is to find ourselves in an environment that promises us adventure, power, joy, growth, transformation of ourselves and the world - and, at the same time, that threatens to destroy everything we have, everything we know, everything we are" (1988, 15). In that work Berman shows how the cultural and political forms that emerge out of the conditions of modernity can be arrayed along a dialectic between "thrill and dread," between the "will to change" and a "terror of disorientation and disintegration, of life falling apart" (13). Although Berman pays little attention to the emergence of science fiction in that work, the genre might have been his best example of the tension he identifies as the crux of modernity and the engine of literary and artistic modernism. Virtually every science fiction story ever conceived oscillates between the promise of utopia and the threat of apocalypse.

The origins of science fiction as a genre have been traced from the early twentiethcentury pulp magazines that first coined the term back through the Gothic novels of the early nineteenth century to the imaginary voyages and "Oriental Tales" of the early modern period, even as far back as the religious and mythological foundations of culture itself: the Bhagavad Gita, the Epic of Gilgamesh, the Book of Genesis. In this way the spatial and temporal constraints of this volume that might initially flummox us-how to begin to talk about the emergence of science fiction without reference to More, Swift, Shelley, Poe, Verne, Wells, Capek, or Zamyatin-can also come as something of a relief; if nothing else they spare us from any impulse towards a total history of the emergence of the genre and allow us to focus instead on the indelible stamp left by American writers on the formation and early history of science fiction.

The term itself — science fiction - was coined surprisingly late, emerging only in the late ig2os out of the pages of Hugo Gernsback's Amazing Stories as the consensus name for a genre that previously had been variously described as "scientific 
romance," fantasy, or "weird tales." In practice the name "science fiction" quickly came to function as a principle of exclusion as much as inclusion. Whereas once all manner of imaginative and speculative fantasies might have seemed of a piece-and indeed would have appeared comfortably together in an earlier publication such as Weird Tales-Gernsback's intervention established a generic divide between science fiction and other modes of fantasy that continues to vex critics.

Likewise, the far-flung consequences of the Gernsback revolution remain alive in the divide that still separates the SCIENCE FICTION \& FANTASY shelf from FICTION \& LITERATURE in contemporary bookstores. While before Amazing Stories such literary authors as Mark Twain, Edgar Allan Poe, Nathaniel Hawthorne, Jack London, and Charlotte Perkins Gilman could write stories of improbable experiences and fantastic inventions that appear in retrospect to be science fictions, after Gernsback science fiction was situated primarily in the pulps, the sort of juvenile indulgence a "real writer" ought to avoid. This divide between the "mature" and "serious" character of literature and the allegedly juvenile and frivolous speculations of science fiction is highly naturalized today, but the history of its development can be traced across our period.

Most contemporary readers of Twain would be surprised to discover, for instance, that when Huck Finn announces his intent to "light out for the Territory ahead of the rest" at the end of that quintessential American novel (ch. 43), Adventures of Huckleberry Finn (1885), his frontier destination turns out to be not California, Texas, or Oregon, but Africa in Tom Sawyer Abroad (1894), and his unlikely mode of transport neither raft nor transcontinental train but a hot-air balloon ripped from the pages of Jules Verne. The contemporary conspiracy of parents, teachers, scholars, and critics to pretend Tom Sawyer Abroad was never written reflects, in miniature, what happens to the creative practices that make up science fiction between 1870 and 1940. Beginning the period critically unrecognized but firmly in the literary and cultural mainstream, science fiction entered 1940 as an established community of discourse at the cost of a newfound marginality, a tradeoff that has haunted the genre for decades.

\section{Science Fiction and Utopia}

Few have captured the difficulty facing critical analysis of science fiction as well as Everett F. Bleiler in his mammoth compilation of the emergence of science fiction, Science Fiction: The Early Years, where he notes the central paradox of science fiction studies: everyone knows what science fiction is, but no one can satisfactorily define it (I990, xi). Darko Suvin offered the definition that has most nearly approached consensus when, in 1972, he defined science fiction as the literature of cognitive estrangement-and even this definition is less consensus than the starting gun for decades of arguments. 
Unpacking the two terms, we have cognition-including "not only natural but also all the cultural or historical sciences and even scholarship" (1979, 13) —and estrangement, derived from the ostranenie of the Russian formalists and Brecht's famous $\mathrm{V}$-effect to denote the opening of the mind to previously unimagined alternatives, which, in turn, cast new and unexpected light on everyday life (6). Consequently, Suvin and the science fiction theorists influenced by his approach have approached science fiction through the relationship between cognitive estrangement and utopia, with Suvin fond of describing science fiction as both daughter and aunt of utopian literature to suggest the extent to which each genre encompasses the other (2010, 39, 43).

We find both these genres at work in the best studied of the proto-science-fiction novels of turn-of-the-century America, Edward Bellamy's 1888 utopia, Looking Backward: 2000-1887, whose mammoth popularity and outsized cultural influence would demand special attention in any study of the period independently of the science fiction context. Within just two years of its publication, the book had already sold more than two hundred thousand copies, as Phillip Wegner notes in Imaginary Communities, and ultimately was only the second American work of fiction to sell more than one million, making it not only the most popular and influential of the proto-science-fictions to be published in the pre-Gernsback era but arguably the most important work of fiction of its day. Translated into twenty languages, Looking Backward spawned a wide host of imitators and detractors both domestically and overseas, almost singlehandedly launching a craze in Utopian fiction that would last for decades and even spawning a real-world political movement dubbed "Nationalism" that was promulgated by the springing up of "Bellamy Clubs" nationwide. In terms of circulating and popularizing socialist ideas, Looking Backward is arguably second in influence only to Marx's Capital.

Looking Backward exemplifies the electric charge of novelty and possibility that Berman identified as characteristic of the modern world-a world that not only can change, but is changing, day by day, in fundamental and irreversible ways. The novel is the story of Julian West, a privileged scion of Old Boston who goes to sleep in the year 1887 only to awaken II 3 years later in the transformed America of the year 2000. West never returns to 1887 , and the book is presented as if it has been published in the very future it depicts-rendering the mere act of reading the novel at all an impossible temporal paradox. The last chapters further highlight the inaccessibility of Looking Backward's utopia in a clever twist on the already clichéd "dream ending" of speculative fiction: West's narrator briefly reawakens near the end of the novel back in the nineteenth century, finding himself alienated and alone in an inequitable social context he now recognizes as a nightmare-only to reawaken a second time, safe and secure in the year 2000, forever separated from his 1888 public by the unnavigable gulf of time.

The book was published with a preface from the "Historical Section of Shawmut College" dated December 26, 2000, which seeks to assure the disbelieving readership 
of utopia that, yes, things had really been this bad just one century earlier: "How strange and well-nigh incredible does it seem that so prodigious a moral and material transformation as has taken place since then could have been accomplished in so brief an interval!" (preface). Life in Bellamy's utopia synthesizes the classless communism that culminates Marx's historical materialist theory of history with the productivity and creativity of capitalism through a unique bloodless revolution. The ever-growing trusts, syndicates, and monopolies characteristic of American capitalism are finally merged into a single monolithic "Great Trust" that employs every worker and provides every good, and as a consequence becomes indistinguishable from the state. In such a context the profit-centered competitiveness that had previously organized capitalist expansion no longer has any meaning, allowing capitalism unexpectedly to transform itself in the service of the public good. In Bellamy's utopia private luxury has been abolished; all workers are paid an equal wage and have an equal share in the proceeds of their collective endeavors. The citizens of this army of labor are motivated not by greed or self-interest, but by "service of the nation, patriotism, passion for humanity" (ch. 9), a transformation of values so complete that such seemingly essential human vices as dishonesty and deception are now anachronistic.

Contemporary readers have been starkly divided on the desirability of the utopia Looking Backward describes, with many (Darko Suvin and Fredric Jameson prominent among them) much preferring British author William Morris's more traditionally socialist retort, News from Nowhere (I890). Raymond Williams acknowledged the widespread anxiety about Bellamy's reduction of social relations to a well-ordered mechanism by noting its "overriding rationalism" and calling the book a utopia "without desire" (2OIO, IOI); David Ketterer goes further still in calling Bellamy's future America "a dystopian society in which the citizens have evolved, or rather devolved, into machines" (1974, II3). Even contemporary critics more favorably disposed to Bellamy are not without their reservations; Paul K. Alkon attributes common "misunderstanding" of the book's proposals to "Bellamy's inability to show vividly the superiority or even the existence of the art, music, and literature that we are assured abound alongside mechanical inventions in his twenty-first century" (2002, II2).

In an analysis that extends beyond Bellamy to the utopian form as such, Marc Angenot reminds us that utopian texts like Looking Backwards are always, by their nature, "equivocal and ambiguous," and must be read as cognitive estrangementsas critiques of what already exists-rather than genuine predictions of the future or positive platforms for change (2000, IIO-II). But the temptation to quibble over the details proved as impossible to resist in Bellamy's contemporaries as in his later critics; Bellamy's work divided its contemporaneous readership, inspiring as many as it horrified. There were numerous responses to the work, many of them fictional treatments often employing Julian West himself as the main character, including Bellamy's own sequel, Equality (1897), intended to shore up points he felt were lacking in the original. 
Many of these dreams of the future have now been entirely forgotten. Richard C. Michaelis's procapitalist retort Looking Further Forward (1890), for instance, rejects both the thesis that capitalism will be overturned and the thesis that it should be. Instead, Darwin's theory of evolution — evoked by Bellamy as a scientific grounding for his prognostications-is employed in the other direction: "Inequality is the law of nature and the attempt to establish equality is therefore unnatural and absurd" (ch. 3). Similarly reactionary replies include Arthur Dudley Vinton's racist Looking Further Backward (1890), an early Yellow Peril story in which the Chinese invade the utopia of Looking Backward, which proves completely unable to defend itself, and J. W. Roberts's anti-utopian Looking Within (1893), which sought to explicate the "misleading tendencies" of Looking Backward through the experiences of James North, who discovers that by 2025 Bellamy's utopia must revert to capitalism in order to escape the corruption that has come to plague it. Former US Congressman Ignatius Donnelly's Caesar's Column (I890) takes Bellamy's basic recognition of an America divided by class in a much more dystopian direction, with the class struggle between capitalist oligarchs and exploited workers culminating not in paradise, but in the "Caesar's column" of the title: an immense mass grave, filled in by oppressors and oppressed alike and covered over with cement to stand forever as a horrible monument to man's brutality (ch. 36).

On the other side of Donnelly's pessimism we find George Allan England's The Air Trust (1915), which explores a sinister robber baron's attempt to privatize the air itself, provoking a socialist revolution to defend the right to breathe. Jack London, too, takes up the terrain pioneered by Bellamy with his socialist novel The Iron Heel (1908), depicting the revolution from the perspective of a historian annotating a twentieth-century manuscript called the "Everhard Manuscript" from the perspective of the year 4I9 BOM (Brotherhood of Man)—approximately 2600 A.D. London anticipates the fascist takeovers of the 1930s through his depiction of the Oligarchy, a union between business monopolists and the state that leads not to state socialism, as in Bellamy, but to widespread exploitation and misery under a newly asserted "divine right" of capitalists to rule (ch. 4). The Iron Heel is perhaps unique in the utopian subgenre for its relentless devotion to a long-term perspective (on The Iron Heel as dystopic science fiction, see Chapter 33 in this volume). The revolution takes approximately three hundred years, including not only the First and Second Revolts that appear in its pages, and "the tortuous and distorted evolution of the next three centuries would compel a Third Revolt and a Fourth Revolt, and many Revolts, all drowned in seas of blood, ere the world-movement of labor should come into its own" (foreword). The novel ultimately breaks off in the middle of a sentence, shortly before the moment its female narrator, Avis Everhard, is captured and killed by police. The final achievement of global justice may be a happy achievement, but the cost in blood and years is so dire as to shrivel hope itself.

More generally optimistic are the feminist utopias that arose in Bellamy's wake, the most widely read of which today is Charlotte Perkins Gilman's Herland, serialized 
in Gilman's magazine Forerunner beginning in 1915 and, largely forgotten before its rediscovery in the late 1970 , celebrated now as an anticipation of later, more explicitly science fictional feminist utopias. Such novels were generally preoccupied by the problem of what to do about childbearing and reproduction (especially once men have been eliminated). Gilman's approach is astounding: after a devastating series of wars, natural disasters, and gender revolts conspire to kill off every male and leave Herland permanently isolated from the surrounding world, the remaining Herlanders discover a woman who is able to reproduce by parthenogenesis, giving birth to five children, each of whom gives birth in turn to five more (ch. 5). The pattern holds until Herland has reached its optimum population, at which time (in defiance of Malthusian pessimism about the inevitability of overpopulation) the women come together and rationally decide to hold their population permanently steady: "With our best endeavors this country will support about so many people, with the standard of peace, comfort, health, beauty, and progress we demand. Very well. That is all the people we shall make" (ch. 6).

The three male explorers who discover Herland by chance find a nation lacking war, poverty and exploitation, and crime and punishment, as well as (naturally) the oppression of women-a point underscored in Gilman's rarely read sequel, With Her in Ourland (1916), in which one of the explorers brings his Herlandian wife to America to show her his home, only to see her spend the trip entirely aghast. The men begin Herland with open imperialist ambitions, and at least one of them still intends at the end to return to Herland with an expeditionary force despite a promise never to reveal its location. The Herlanders, for their part, likewise view the men with a colonizers' gaze, as seen in the report generated at the first sighting of the men: "From another country. Probably men. Evidently highly civilized. Doubtless possessed of much valuable knowledge. May be dangerous. Catch them if possible; tame and train them if necessary. This may be a chance to re-establish a bi-sexual state for our people" (ch. 8, emphasis added).

As is typical of such literary utopias, Herland is not an earnest proposal for alternative social organization, but an opportunity for satire and social critique, as when Herland's women discover that the explorers' beneficent claim that "We do not allow our women to work. Women are loved-idolized-honored-kept in the home to care for the children" is compromised by the fact that women "of the poorer sort" do work in America after all-a mere seven or eight million people at the time (ch. 5). Similar questions abound about gender relations, capitalism, politics, and religion, each serving to skewer the conventional wisdom of the day, particularly with respect to feminism and gender equality. "It is only in social relations that we are human," Gilman claimed elsewhere in her work: "To be human, women must share in the totality of humanity's common life" (qtd. in Lane [1979], xi). The narrative thrust of Herland is to raise the consciousness of at least one of the male explorers until he is finally able to view the inhabitants of Herland not as women, but as people. 
In the face of feminist scholarship that has largely embraced Herland since its republication (and rediscovery) in 1970, Alys Eve Weinbaum takes up the unhappy task of demystifying the novel in her book Wayward Reproductions, calling attention to Herland's erasure of race and violence in the colonial encounter, as well as its reinscription of eugenic thinking about white purity current at the time (2004). (The Herlanders are explicitly eugenic, both pressing on "the lowest types" of their population not to breed and aggressively removing custody from any woman deemed unfit to mother a child [1915, ch. 7].) This unfortunate tendency is much more obvious in With Her in Ourland, which sees its enlightened Herlandian heroine calling for assimilation for "tribal" Jews and noting that the presence of an "ill-assorted and unassimilable mass of human material" — unskilled immigrant workers—-makes democracy impossible in America as "only some races-or some individuals in a given race- have reached the democratic stage." Such unfortunate episodes help explain why Ourland is less widely read than Herland today.

\section{Science Fiction and Imperialism}

The presence of colonialist, eugenicist, and racist themes lurking not only in Herland, but in so many of the utopias already discussed above, has helped motivate the recent "imperial turn" in science fiction studies, which significantly complicates the critical interest in utopia by calling attention to the historical relationship between science fiction and imperialist fantasies. In his essay "Science Fiction and Empire," Istvan Csicsery-Ronay, Jr., notes that "The dominant sf nations are precisely those that attempted to expand beyond their national borders in imperialist projects: Britain, France, Germany, Soviet Russia, Japan, and the US," with periods of most intense interest in science fiction coinciding with periods of expansion beyond the borders of the nation (2003, 23I). Early science fiction registers the central importance of technology as a tool for imperial domination, with technological innovation serving as "not only a precondition for the physical expansion of the imperialist countries but an immanent driving force" that "facilitated the subjugation of less developed cultures, wove converging networks of technical administration, and established standards of 'objective measurement' that led inevitably to myths of racial and national supremacy" (233). Csicsery-Ronay notes too how "fantasies of physical mastery and engineering know-how" that accompanied this technological expertise dominated early science fiction (234), connecting these once again to the similar fantasies of mastery that structured the ideologies of imperialism and race war during the period.

In Colonialism and the Emergence of Science Fiction, John Rieder likewise finds colonial and imperial ideology at the heart of science fiction's imagination of other places and times, with power inevitably distributed along a rhetoric of "progress" that either places white Europeans at the culminating apex of human history or 
threatens them with supersession from either terrestrial or extraterrestrial competitors. Lost races, first contacts, alien invasions - such narratives draw not only from the history of colonial and imperial encounters, but also and perhaps most crucially from pseudo-Darwinian discourse about racial superiority and inferiority. The popularity of "Yellow Peril" fictions at the turn of the century-first depicting strategies by which the people of Asia might be wiped out by ever-more efficient military technology, and then turning inevitably to the threat that such weapons might someday be loosed on the US population instead-represent only the worst extremes of such virulent fantasies. So-called edisonades, dime-novel stories of fantastic inventions, likewise frequently hinged on the invention of fantastic superweapons, perhaps most vividly in Garrett Serviss's Edison's Conquest of Mars (I898), a sequel to Wells's War of the Worlds in which Thomas Edison himself develops both flying machines that can reach Mars and disintegrator rays to lay waste to the Martian population once human beings arrive. In Edgar Rice Burrough's Barsoom series (1912-64), the imperial encounter between East and West is similarly transposed to Mars, where Burroughs's Great White Hero John Carter encounters and subdues monstrous green- and red-skinned "savages" on the surface of Mars through ingenuity and physical superiority in stories that anticipate the adventures of his later hero, Tarzan. Even edisonades taking a less gung-ho attitude towards imperialism - such as the popular Franke Reade series of dime novels (1892-99) primarily authored by "Noname" Luis Senarens-frequently employed dual-use technologies of transportation and communication that were improved versions of those being employed in colonial and imperial wars.

From the perspective of the imperial turn, the best example of nineteenth-century American proto-science fiction may be not Looking Backward but rather Mark Twain in his quasi-reply, A Connecticut Yankee in King Arthur's Court (I889), which makes intriguingly literal the retemporalizing gesture that Johannes Fabian identified as a crucial strategy for the justification of imperial violence: the "assign[ing] to the conquered populations a different time" $(1983,30)$. In what is believed to be the first such time-travel story in English literature, Twain inverts and destabilizes the usual imperial narrative by having his "Connecticut Yankee" appear in the imperial West's own preindustrial past. (An interesting complement to Twain's gesture can be found in John Ames Mitchell's lesser-known The Last American, published the same year, which satirically recounts the discovery and excavation of the ruins of "Nhu-Yok," largest city of the lost Mehrikan empire, by Persian archaeologists in the year 295I.) Hit on the head with a crowbar during a fight with one of his subordinates, factory superintendent Hank Morgan (an engineer who has "learned to make everything - guns, revolvers, cannon, boilers, engines, all sorts of laboursaving machinery" [1889, "The Stranger's History"]) finds himself awakening in Arthurian England, transported in both space and time. With his advanced scientific and technical know-how (including the fortuitous knowledge of an impending total solar eclipse), Morgan quickly displaces the magician Merlin to take administrative 
control of Camelot, implementing a plan for modernization and development that rivals any attempted in actual imperial history.

A Connecticut Yankee seems at first as if it will conform to a familiar nineteenthcentury narrative of progress; critics frequently begin their discussion of $A$ Connecticut Yankee with Twain's dream that spawned the novel:

Dream of being a knight errant in armor in the middle ages. Have the notions and habits of thought in the present day mixed with the necessities of that. No pockets in the armor. No way to manage certain requirements of nature. Can't scratch. Cold in the head—can't blow—can't get at handkerchief, can't use iron sleeve. Iron gets red hot in the sun-leaks in the rain, gets white with frost and freezes me solid in winter. Suffer from lice and fleas. Make disagreeable clatter when I enter church. Can't dress or undress myself. Always getting struck by lightning. Fall down, can't get up. (1889, preface)

The description of the dream-Twain's apparent first notes for the novel—suggests that it is the past that is the intended victim of his satire. And although Twain is not commonly associated with optimism about either the present or the future, optimistic attitudes can occasionally be found elsewhere in his work. He praised Looking Backward, notably, as "the latest and best of all the Bibles," and said Bellamy "has made the accepted heaven paltry by inventing a better one on Earth" (preface). The excitement of this benediction calls to mind Twain's unexpected (and uncharacteristic) optimism on the occasion of Walt Whitman's seventieth birthday in I889, when he rhapsodized on the coming glories of the twentieth century. "Wait thirty years and then look out over the earth," he writes. "You shall see marvel upon marvels, added to those whose nativity you have witnessed; and conspicuous above them you shall see their formidable Result-Man at almost his full stature at last!- and still growing, visibly growing, while you look" (preface).

But despite these occasional flirtations with optimism, Twain seems constitutionally incapable of holding the feeling for very long. The meeting of the lost Arthurian past with contemporary scientific culture, while seeming to promise advancement, turns by the end of $A$ Connecticut Yankee to utter ruin. The mechanisms of modernity and "progress" that Morgan devises and implements in his capacity as "Boss" of Camelot come to their natural conclusion in the form of a bloody massacre. After Arthur's death Morgan and his men attempt to retain their control of Camelot against the reactionary forces of the nobility and the Church that unite against the Yankee's attempt to establish a Republic. Now we see the other side of technology and progress: dynamite, mines, Gatling guns, and an electric fence quickly decimate a hopelessly outmatched opposing army. "Within ten short minutes after we had opened fire, armed resistance was totally annihilated, the campaign was ended, we fifty four were masters of England! Twenty-five thousand men lay dead around us" (ch. 43). Merlin-not a charlatan after all-soon uses his magic to send the Yankee home, and the Church conspires to cover up all the evidence of his experiment in 
the past, leaving only the Yankee to remember, and to be tortured until his death by horrible and unsettling dreams.

This climactic vision of mass death, facilitated by technologies both already in use and soon to be employed in imperial adventure overseas, is the culmination of a critique of imperialism that is hinted at throughout the novel. The first of Dan Beard's illustrations for the novel, immediately preceding chapter one, likewise suggests that the time travel at the center of the story is related somehow to a critique of global imperialism. The image of a giant statue of a lion, on which a man in a suit and bowler cap stands perched with one hand in his pocket, labeled on the pedestal "THE TALE OF THE LOST LAND," suggests not Arthurian England but Africa. Morgan's first view of Camelot's locals similarly points to questions of race and racialization that were on Twain's mind as his politics turned more and more anti-imperialist in his old age. The peasants of Camelot are "brawny men, with long, coarse, uncombed hair that hung down over their faces and made them look like animals." Many are naked, "but nobody seemed to know it" (ch. I), suggesting both Eden and tropical locales like the Hawaii from which a young Twain reported for the Sacramento Daily Union at the start of his literary career in 1866. In fact, as Fred W. Lorch and Stephen H. Sumida have argued, Hank Morgan's story most likely has its origin in an unfinished novel about Hawaii on which Twain had been working at the time, a project he eventually abandoned in favor of $A$ Connecticut Yankee. That story of a meeting of nineteenth-century industrial society with a preindustrial, pastoral past, beginning with notions of progress and uplift but ultimately culminating in an imperial disaster, turns out to be a closer match to Hawaiian history than Twain could have known at the time; the early violence of the 1887 and I888 uprisings in Hawaii would culminate in a United States-led overthrow of the Hawaiian kingdom and final US annexation by I893. Along the same lines, John Carlos Rowe convincingly links A Connecticut Yankee to Twain's history of growing anti-imperialism over the course of his adult life, a precursor to the anti-imperialist satires he would eventually write during the US military occupation of the Philippines.

While it may seem to contemporary readers "impossible that any reader of A Connecticut Yankee could fail to be disturbed by the violence of its ending," Stephen Railton notes with some surprise that in fact "no contemporary reviewer even mentioned it" $(2004,88)$, speculating that such reviewers may in fact have been unwilling or unable to see this aspect of the narrative. Paul K. Alkon, in contrast, suggests that it is we who are unable to read $A$ Connecticut Yankee with proper objectivity, as the bleak, scorched-earth violence of the ending inevitably recalls for us such "twentieth-century nightmares" as trench warfare, aerial bombing, and nuclear weapons (2002, 133). Despite the book's comedy and ample satiric charms, the abrupt switch into total war at its conclusion makes it difficult for modern readers to see the novel as representing much more than "irreverence, the guillotine, a reign of terror, and a kind of generalized despair" (Kaplan 1991, 296). José Martí offered an exceptionally cogent description of $A$ Connecticut Yankee's irresolvable dialectic 
between optimism and cynicism in his 1890 review, observing, "although it is humorous, as it is said to be, it was written after having cried" (2010, 55).

\section{Science Fiction, Literature, and the Pulps}

In Metamorphoses of Science Fiction, Darko Suvin bemoans the lost tradition of science fiction that might have begun with Twain had "certain fragmentary sketches" found among his papers been completed and published during his life, allowing Twain to eclipse H. G. Wells as "the major turning point in the tradition leading to modern SF" (1979, 20I). But this was not to be-and instead American science fiction descended first into the edisonades and Edgar-Rice-Burroughs-influenced dime novels and then the pulp magazines from which, a century later, it is still in many ways trying to emerge. Hugo Gernsback's vision, not Bellamy's or Twain's, would ultimately shape science fiction's emergence as a genre.

Gernsback's editorial on page one of the first issue of Amazing Stories in 1926 breathlessly announces "a new sort of magazine." Our now- "intimate" relationship with science across all spheres of life from history-making conflicts to everyday domesticity, Gernsback claims, has created "an entirely new world" through which science fiction "blaze[s] a new trail" (1926, 3). This enthusiastic celebration of the new overlooks the fact that this novelty was most commonly expressed, throughout the earliest years of the magazine, in decades-old reprints. In the first six months, only six of the thirty-eight stories published by Gernsback were original to Amazing, and in his first attempt at defining science fiction he describes "the Jules Verne, H. G. Wells, and Edgar Allan Poe type of story-a charming romance intermingled with scientific fact and prophetic vision" $(1926,3)$.

To properly qualify as science fiction in the Gernsbackian mold is to hit each of these three marks: it must be a tale of adventure (often with a love interest) modeled on accurate scientific knowledge and predicting a likely course for technological and scientific advancement. Exemplifying this intersection is Gernsback's own contribution to the genre, Ralph ${ }_{124} C_{4 I+}$ ("one to foresee for one and more"), a "romance of the year 2660," then 750 years hence, which was published as a serial in Gernsback's magazine Modern Electrics (I9II), long before the advent of Amazing Stories. The novel depicts the singular experiences of its title character as he explores the technoutopian world of 2660 until (in an almost perfunctory climax) he battles a Martian brute for the return of the woman he loves.

Contemporary science fiction criticism almost universally derides the novel as unreadable, reflecting the extent to which Gernsback's approach has fallen out of favor (and Gernsback himself is largely unremembered outside of scholarly circles). The novel embodies the worst of the science fiction that is to follow it, with a cardboard-cutout protagonist whose "physical superiority" (while ample) is "as nothing compared to his gigantic mind" (I9II, ch. I) and whose experiences, in lieu 
of a plot, careen from one expository science lesson to another. And yet Gernsback undoubtedly took great pride in the novel's successful predictions, among them (as outlined by the novel's ig5o forwards from Lee de Forest, the inventor of radio, and science fiction author Fletcher Pratt) television, microfilm, air and helicopter travel, lie detectors, talkie film, spaceflight, sleep-learning, night baseball, synthetic fibers, and radar, to name only a few (ch. I).

Of course, science fiction's prognostications are only sporadically accurate, and it is worth noting that Gernsback's invention-oriented notion of science fiction was not the one best loved by the public even in his day. Most of his science-fiction publishing ventures failed, including Amazing, of which Gernsback lost control after declaring bankruptcy in 1929. Of the four science fiction magazines he founded afterwards, most folded or merged after just a single year. Adam Roberts notes that other magazines, like Astounding (founded in 1930), gained prominence in part by rejecting Gernsback's "insistence on didactic science" and instead focusing on "adventure, excitement, and exoticism" (2007, 177). Everett Bleiler, too, notes that Gernsback's preferred theme of technological optimism took a back seat to the unending cavalcade of disaster, catastrophe, and out-and-out apocalypse that actually dominates the science fiction of the period, a preoccupation Bleiler groups under the single evocative heading "Things Go Wrong" (1990, xv). Generally speaking the hegemony of the magazines in US science fiction history resulted from social conditions independent of any writer or editor's vision. As difficult as the Great Depression was for magazine publishers, it was far crueler for book publishers, with publication of original science fiction novels outside serial form essentially drying up until the Second World War. The best-remembered science fiction novelists of the era, like Burroughs, Jack Williamson, and E. E. "Doc" Smith of Skylark of Space fame, were all publishing their books serially in the pulps.

The increasing primacy of the pulps in the late 1920 s and early 1930s established a situation in which science fiction was understood rightly to "belong" to the mass audience of the pulps, and writing in the genre consequently came to be seen as a commercial rather than artistic pursuit. The aura of disposability that accompanies magazines and their (admittedly often-deserved) reputation for low literary quality contributed to the growing popular perception in the United States that science fiction was a fundamentally unserious and unliterary endeavor-in stark contrast to critical reception in Britain, where science fiction novels from authors such as H. G. Wells, Aldous Huxley, George Orwell, Katharine Burdekin, and Olaf Stapledon were treated by reviewers and critics as "serious literature" as late as Nineteen Eighty-Four in 1949 (and even beyond).

This difference in critical reception is not totally unwarranted. Brooks Landon has noted, "Almost every study of science fiction in the twentieth century details an essential difference in 'seriousness' or 'purpose' between American SF and noteworthy strains of well-known SF from the United Kingdom, Eastern Europe, and the Former Soviet Union" (2002, 76-77). The chapter in Adam Roberts's History 
of Science Fiction titled "High Modernist Science Fiction" does not include a single American name, nor does Brian Aldiss's list of the "greater talents" who "most ably put the salt on the tail of the zeitgeist and, by capturing it, seem to defy it and live on." American pulp writers, he admits in contrast, "have by now lost what savour they possessed," telling us "less about the world and more about the tricks of their lowly trade" (1986, 20I-202). Accordingly, Aldiss designates Hugo Gernsback "one of the worst disasters ever to hit the science fiction field" (1986, 202). Darko Suvin speaks for the many who agree with Aldiss when he notes that "the Gernsbacks keep SF alive at the cost of starving, stunting, and deforming it; comparing The Iron Heel with the output in the United States between the World Wars, one strongly suspects the cost is too high" $(1979,23)$.

But the imprint of Gernsback on the genre he helped found remains undeniable. As Gary Westfahl observes, the British and European models for science fiction that predated Gernsback were ultimately not able to survive him. "When [British and European science fiction critics] look at their native literatures in the period from I890 to 1920 , they find more than enough examples of works classifiable as science fiction that are far superior to anything produced in America at that time," Westfahl writes:

but as they extend their chronological surveys past 1920, they watch their own traditions fade and fall apart, while American science fiction expands and grows stronger to the point that, by 1950, American writers and ideas dominated the world, and British and European authors were forced to imitate or respond to the American tradition. $(1998,27)$

Westfahl even catches the Swedish critic Sam J. Lundwall bemoaning that science fiction was "stolen" by Americans from the Europeans (27)!

Perhaps, indeed, there was no such thing as science fiction before Gernsback at all. Although "science fiction" was first used as the name for stories that combine aesthetic pleasure and narrative interest with pedagogical instruction in the sciences in I851, it was Gernsback who (after a brief flirtation with the infelicitous portmanteau "scientifiction") recoined and popularized the term early in his career as a magazine publisher. Consequently Westfahl has argued that the impulse to locate some originpoint for science fiction further and further back in time is fundamentally wrongheaded; the origin of science fiction should instead be located here, with Gernsback in the America of the I920s, the first of the genre's author-editor-critics who, in the act of naming the genre, brought it about.

While frequent attempts have been made to locate the quintessential "Americanness" of post-First World War and especially post-Second World War science fiction in the history, ideology, or material conditions of late-nineteenth and midtwentieth-century America, Westfahl assigns the credit to Gernsback himself, not as writer or editor but as critic, as the founder of a particular literary-critical discourse around which the genre was organized and galvanized. While we might be able to 
recognize relatives of the genre in retrospect, Westfahl argues, it took Gernsback's taxonomic innovation to bring those family resemblances to our attention. "What Gernsback provided," argues Westfahl,

was not simply a set of marketing slogans or slick promotions; he offered a complete theory of science fiction which readers, editors, and writers understood and responded to. ... Because of the stimulating and supportive atmosphere of the commentaries engendered by Gernsback, American science fiction steadily expanded and improved; because of the absence of such commentary, British and European traditions floundered. Simply put, literary criticism made American science fiction great, and that was Gernsback's great contribution to the field. (1998, 28-29)

The medium of the pulps allowed for a level of interactivity among writer, editor, and audience that far surpassed anything to be found in the one-way transmission of the novel; the fan essays, contests, prizes, and letters to the editor to be found in the pulp magazines of the Gernsback era are the earliest forerunners of fan clubs, fanzines, conventions, and Internet comment threads that are still a vital part of the field. Science fiction was conceived and executed as an ongoing, two-way dialogue between writers and readers from its earliest instances in the pulps-and this active reception would prove to be a crucial component for the establishment and growth of science fiction as a popular genre, not only in the pre-Second World War era but in the "Golden Age" and "New Wave" eras that would follow. "How good this magazine will be in the future is up to you," Gernsback writes in that first Amazing Stories editorial in 1926; "Read Amazing Stories—get your friends to read it and then write us what you think of it."

From the many fans influenced by Gernsback's call to community, who loosely organized themselves into "science clubs" to discuss the work, Bleiler identifies a core of one hundred of so "trufans"- those for whom science fiction was as much an ethos as an aesthetic pleasure-from whose list of members can be distilled a significant fraction of the writers and editors who would soon inaugurate what is commonly known as the Golden Age of Science Fiction, beginning around 1940: Isaac Asimov, James Blish, Arthur C. Clarke, John Wyndham Harris, Damon Knight, Judith Merrill, Sam Moskowitz, and Donald Wollheim (1990, xxix-xxx). In the coming decades this group would take over the field, becoming the establishment that the writer-critic-fans of the "New Wave" of the I960s and I970s would in turn pit themselves against in both critique and homage.

Still, despite the advantages this critical community offered to the growth of science fiction, one cannot help but imagine an alternate history of science fiction that is organized not around Gernsback and the pulps but instead (as in the European tradition) around the "slipstream" novels that quietly deploy the science fictional imagination within the literary canon. The Afrofuturist school of literary criticism, beginning in the late 1990s, has already convincingly organized its intervention into literary history along these lines, arguing, in Greg Tate's formulation, that "Black 
people live the estrangement that science fiction writers imagine" (qtd. in Dery 1995, 208) and, in Isiah Lavender's, "the blunt thesis underlying Afrofuturism is that all black cultural production in the new world is SF" $(2007,187)$. Such a thesis need not look far to find its evidence. Pauline Hopkins's OfOne Blood (1903) rewrites the popular "lost race" tale of early science fiction to describe an unknown Ethiopian kingdom from which all human civilization originated, anticipating not only the Africanist movement in historical studies, but also the science fictional cosmology of the Nation of Islam and 1970s Afrofuturism in music and film. Among Sutton E. Griggs's self-published novels, which were widely read among African Americans but "virtually unknown to white Americans of his time" (1899, "Preface"), Imperium in Imperio (1899) can be positioned at the intersection of political science fiction, conspiracy fiction, and utopianism in its depiction of an African American shadow government operating in secret in Washington, DC. W. E. B. Du Bois, too, borrows from science fiction's imagination of disaster in "The Comet," the short story that closes his 1920 book Darkwater. In that story the close pass of a comet apparently destroys all civilization on earth and leaves New York City populated by only two people, a black man and a white woman. The new Eden promised by this encounter, populated by a once-again united human race undivided against itself, is soon disrupted by the discovery that the disaster has only been local after all; soon other survivors appear, including white men who seek to lynch Jim for his presumption that racial inequality could be suspended even by the end of the world. George $S$. Schuyler's Harlem Renaissance novel Black No More (193I) similarly employs science fictional tropes-here, fantastic invention-to provide the grounding for his skewering of white racism (on Schuyler's Black No More, see Chapters 28 and 30 in this volume). The development of a skin-whitening treatment that can turn African Americans "whiter than white" (ch. 13) serves as a clever deconstruction of America's fantasies of race, culminating, at the end of the novel, in the entire population (white and black alike) turning to tanning creams to darken their skin, in order to prove to their peers the fantasy that their whiteness is genuine and real.

The science fictionalization of the canon need not stop there. The immigrant fiction of the turn of the century is surely a close cousin of the science fiction novel, with its characteristic cognitive estrangement originating not from the physical laws of science, but from the social laws of culture, language, and migration. These writers describe lives that have been transformed beyond imagination - and of disparate nations that stand in no closer relation to each other than distant planets. "I was born, I have lived, and I have been made over," begins Polotsk-born Mary Antin in her autobiography, The Promised Land (1912), in language that suggests the estranging experience of the immigrant is the same whether the ultimate destination is Manhattan or Mars: "Is it not time to write my life's story? I am just as much out of the way as if I were dead, for I am absolutely other than the person whose story I have to tell. Physical continuity with my earlier self is no disadvantage. I could speak in the third person and not feel that I was masquerading. I can analyze my subject, I can 
reveal everything; for she, and not $I$, is my real heroine. My life I have still to live; her life ended when mine began" (1912, introduction). Abraham Cahan's Russianborn David Levinsky (1917) likewise views his past in terms that suggest radical selfdivision and ostranenie, a "metamorphosis" that leaves a single human body forever divided between two warring halves (ch. I), a past and a present that cannot be made to fit together again. Jerry Siegel and Joe Shuster translated the experiences of their immigrant parents into the origin story of the genre-establishing comic book hero Superman (1938), last son of a lost world to which he can never return - and it is surely no coincidence that the father of science fiction, Hugo Gernsback himself, was an immigrant from Luxembourg.

The aesthetics of cognitive estrangement — of realities that are pregnant with multiplicity and alterity, of individuals who are more than themselves, of pasts and futures that improbably meet somewhere in the middle-can give us fresh purchase on literary contexts as diverse as Yoknapatawpha County, West Egg, New York; Winesburg, Ohio; and expatriate Paris. What for that matter could be more manifestly science fictional than the alternate history that makes up Sinclair Lewis's It Can't Happen Here (1935), in which a Hitler-like populist becomes dictator of a fascist United States, or the haunting nightmare of Dalton Trumbo's antiwar classic Johnny Got His Gun (1938), whose tragic soldier-narrator is kept alive in alienated misery despite the loss of his arms, legs, eyes, ears, and tongue in the trenches of the First World War? The persistent discovery of deeper and deeper kinship between science fiction and the literary canon with which it is inevitably juxtaposed suggests there may be more than mere bravado behind the declaration of John W. Campbell (whose 1938 ascension to the editorship of Astounding Science Fiction marks both the end of the period covered by this book and the beginning of science fiction's "Golden Age") that "'mainstream literature' is actually a special subgroup of the field of science fiction-for science fiction deals with all places in the Universe, and all times in Eternity" (1963, xv). The law of genre, as Jacques Derrida famously observed, is as much a "principle of contamination" as it is a "line of demarcation" (I980, 57); one hundred years after and six hundred and fifty years before Ralph ${ }_{22} 4 \mathrm{C}$ $4 I+$, science fiction, like some strange creature out of its own pages, still cannot be kept safely confined in its cage. 